\title{
Evaluation of Usefulness of Three Serological Tests Using Native Crude Antigen in Diagnosis of Hepatic Cystic Echinococcosis Patients
}

\author{
Mesut Akil1', Ahmet Ozkeklikci², Eylem Akdur Ozturk'1, Aygul Sadiqova', Nuray Altintas ${ }^{3}$, \\ Selda Karamil ${ }^{3}$, Ozge Sarica Yilmaz ${ }^{3}$, Aysegul Unver ${ }^{1}$, Nazmiye Altintas ${ }^{1 *}$ \\ ${ }^{1}$ Department of Parasitology, Faculty of Medicine, Ege University, Izmir, Turkey \\ ${ }^{2}$ Department of Microbiology, Dr. Ersin Arslan State Hospital, Gaziantep, Turkey \\ ${ }^{3}$ Department of Medical Biology, Faculty of Medicine, Celal Bayar University, Manisa, Turkey \\ Email: ^nazaltintas1@gmail.com
}

How to cite this paper: Akil, M., Ozkeklikci, A., Ozturk, E.A., Sadiqova, A., Altintas, N., Karamil, S., Yilmaz, O.S., Unver, A. and Altintas, N. (2021) Evaluation of Usefulness of Three Serological Tests Using Native Crude Antigen in Diagnosis of Hepatic Cystic Echinococcosis Patients. Open Journal of Medical Microbiology, 11, 69-79. https://doi.org/10.4236/ojmm.2021.112006

Received: February 7, 2021

Accepted: April 22, 2021

Published: April 25, 2021

Copyright $\odot 2021$ by author(s) and Scientific Research Publishing Inc. This work is licensed under the Creative Commons Attribution International License (CC BY 4.0).

http://creativecommons.org/licenses/by/4.0/

\begin{abstract}
Objective: To evaluate three different serological tests [Indirect Hemaglutination (IHA), Enzyme Linked Immunosorbent Assay (ELISA) and Western Blotting (WB)] using native crude antigen for diagnosis of hepatic cystic echinococcosis (HCE) patients. Materials and Methods: Sheep hydatid fluid (HF) was collected from fertile cysts obtained from a slaughterhouse and used as an antigen. Forty patients who were attended the Dr. Ersin Arslan Training and Research Hospital in Gaziantep, Turkey, were investigated. Serum samples were obtained from surgically confirmed CE patients. Healthy Turkish people and 16 patients with other helminthic infections were included as a control group. Results: Of the 40 analyzed patients, 10 (25\%) were men and 30 (75\%) were female. The average age was 46.97 years (s.d.; 18.95). The majority of the patients had a single cystic lesion situated in one lobe of the liver (usually in the right lobe) (55\%), 32.5\% of patients had two cystic lesions and $12.5 \%$ of patients had multiple cyst formations with various numbers. In all cases, ultrasound (US) examinations were positive and the size of cysts was between $2.1-12.7 \mathrm{~cm}$. Twenty-three patients of the total 40 patients were classified according to the WHO classification system based on US findings. According to the results of $\mathrm{WB}$ analysis, molecular weights of $8 \mathrm{kDa}(80 \%)$, $12 \mathrm{kDa}(80 \%), 22-24 \mathrm{kDa}(97.5 \%), 26 \mathrm{kDa}(97.5 \%), 34 \mathrm{kDa}(100 \%), 36-38$ $\mathrm{kDa}(90 \%), 45-50-55 \mathrm{kDa}(97.5 \%)$, and $60-75 \mathrm{kDa}(97.5 \%)$ bands were identified. But 34,50 , and $55 \mathrm{kDa}$ bands were also found in other helminthic diseases. Conclusion: The specificity and sensitivity of three serological tests (IHA, ELISA and WB) using crude antigen were compared by diagnosing hepatic cystic echinococcosis patients. IHA and ELISA showed high sensitivity
\end{abstract}


but low specificity. Western blotting showed low sensitivity but high specificity.

\section{Keywords}

Cystic Echinococcosis, Serodiagnosis, Enzyme Linked Immunosorbent Assay, Indirect Hemagglutination Assay, Western Blotting

\section{Introduction}

Cystic echinococcosis (CE) is a parasitic disease caused by the ingestion of Echinococcus granulosus egg which is found in dog feces. The life cycle of this parasite involves carnivores (such as dogs) as definitive hosts and herbivores (such as sheep and cattle) and humans (which is accidental) as intermediate hosts [1]. Humans are infected by the larval stage of tapeworm and hydatid cysts exist mostly in the liver $(65 \%-70 \%)$ and lungs $(20 \%-25 \%)$ but also other organs (kidney $2 \%$, spleen $2 \%$ and brain less than $2 \%$, etc.) [2] [3]. Cystic echinococcosis is one of the most important parasitic diseases and it is common almost all over the world. Turkey is also one of the endemic countries and CE poses a problem in terms of public health and the economy. In Turkey, it was stated that approximately 2663 patients every year had operations because of CE [4]. According to the data of the Ministry of Health; 408 annual cases were reported in 2008 , and this number reached 1.867 by the end of 2019 . The morbidity rate reported as 0.57 per 100.000 in 2008 was reported as 2.08 in 2019 [5].

Diagnostic methods of CE depend on the facilities in hospitals and laboratories therefore it is complicated. Although there are various imaging modalities such as ultrasonography (US), computed tomography (CT) and magnetic resonance imaging (MRI), especially US is the main modality for hepatic cystic echinococcosis (HCE). US has been used to detect a variety of pathologies, including parasitic infections, since the 1970s, with the use of portable US scanners in rural communities starting in the 1980s [6]. The current international WHO-IWGE (Informal Working Group on Echinococcosis) classification of CE cyst stages is based on the pathognomonic features of cysts on USG, and guides their clinical management. For the analysis, CE cysts were grouped into active [CL (cystic lesion, if active) $\mathrm{CE} 1, \mathrm{CE} 2, \mathrm{CE} 3 \mathrm{a}$ and $\mathrm{CE} 3 \mathrm{~b}$ ] and inactive (CE4 and CE5). Effective serological tests for CE diagnosis would be of great help to define and support cyst status [7] [8] [9] [10].

There is currently no standard, highly sensitive and specific serological test for $\mathrm{CE}$ antibody detection [11]. The main serological methods used for human CE diagnosis are based on the detection of specific IgG antibodies. Serological tools support imaging techniques. The available tests are based on antibodies against crude antigens and low or no usefulness for the follow-up of patients during the treatment. Specific recombinant antigens have good potential as diagnostic and follow-up tools for CE, but progress in this field is hampered by a lack of stan- 
dardization. Many authors have focused their research both on recombinant proteins and on synthetic peptides, to develop more sensitive and specific tests. Numerous recombinant proteins and related peptides, mainly derived from antigen $B$ and antigen 5, have been tested for the detection and follow-up of antibodies in correlation with US findings. But, available data were generated from small and underpowered clinical studies that have shown dissimilar Se and Sp for the same recombinant antigen [12].

Serologic methods based on the search for specific antibodies in the patient's serum are also needed in the diagnosis of HCE. Different antigens have been used for serodiagnosis of CE until now [13] [14]. Serological testing is usually based upon the use of crude antigens prepared from the metacestodes of E. granulosus. Immunofluorescence antibody tests (IFAT), based on protoscoleces of E. granulosus, have been in use since 1967 [15] and can have diagnostic sensitivities of $>95 \%$ in hepatic CE but suffer from relatively poor specificities [16]. A number of recombinant antigens have also been developed, but their use in standard diagnostic laboratories is limited [17]. On the other hand, the use of purified antigens improves the specificity of serological assays but may lead to a loss of sensitivity [2]. Combination of imaging and serological tests such as Indirect Hemaglutination Assay (IHA), Enzyme Linked Immunosorbent Assay (ELISA) and Western-Blotting (WB) provides diagnostic confirmation.

In this study, we used the sera of HCE patients which were found positive by IHA, ELISA, WB tests and liver ultrasonographic images. The aim of this study was to demonstrate the usefulness of hydatid cyst fluid (HCF) collected from cysts obtained from infected sheep in Turkey and to evaluate three different serological tests (IHA, ELISA and WB) using native crude antigen. Also, to evaluate the clinical findings regarding cyst localized in the liver and individual serological responses in patients with $\mathrm{CE}$. And to present the results of diagnostic performance of the WB test compared with IHA and ELISA tests in patients with liver CE.

\section{Materials and Methods}

\subsection{Crude Antigen Preparation}

The fertile cysts in a sheep were obtained from a slaughterhouse of city Izmir, Turkey. Hydatid cyst fluid (HCF) was aspirated using an aseptic injector and protoscoleces were detected in microscopic examination for fertility. Hydatid cyst fluid was centrifuged at $10,000 \mathrm{~g}$ for 20 minutes at $4^{\circ} \mathrm{C}$. The supernatant was separated and its protein concentration was calculated using the Bradford protein assay kit (Bio-Rad) and bovine plasma gamma globulin as a standard. Protein concentration was found $2.65 \mathrm{mg} / \mathrm{ml}$ [18]. Then supernatant stored at $-20^{\circ} \mathrm{C}$ as a hydatid crude antigen until used.

\subsection{Serum Samples}

Forty patients who were hospitalized in Dr. Ersin Arslan Training and Research 
Hospital in Gaziantep, Turkey were included in this study. All patients had cystic structures by the US examination and were investigated by commercial IHA test (Fumouze diagnostic, France) and in-house ELISA. We used WB analysis as a confirmation test for retesting the seropositive serum samples detected by both IHA and ELISA tests. Sera from healthy volunteers and from 16 patients with other parasitic diseases such as Fascioliasis (n: 5), Trichinellosis (n: 3), Toxocariasis (n: 4), Leishmaniasis (n: 3 ) and Giardiasis (n: 1) were included as a control group. These sera were divided into aliquots and kept at $-20^{\circ} \mathrm{C}$ until use.

\subsection{Indirect Hemaglutination Assay (IHA)}

Commercial IHA test (Fumouze diagnostic, France) was used according to manufacturer's protocol.

\subsection{Enzyme Linked Immunosorbent Assay (ELISA)}

ELISA was carried out in flat-bottom 96-well microplates (Nunc, Maxisorp, Roskilde, Denmark) as previously described [2]. Optimal antigen concentrations are known based on the results of previous titration experiments for ELISA. $50 \mu \mathrm{l}$ HCF antigen diluted in $11 \mathrm{ml}$ Phosphate Buffered Saline (PBS, pH: 7.4) and plates were coated with it at $100 \mu \mathrm{l}$ per well. Then, plates were kept at $4^{\circ} \mathrm{C}$ overnight for incubation. Following to washing three times with PBS, plates were blocked with $0.25 \%$ casein (PBS/casein) for 30 minutes. Sera were diluted in PBS/casein (1:100 dilution), incubated at room temperature for 1 hour. After washing three times again, plates were incubated 1 hour with peroxidase-conjugated anti-human IgG in $\mathrm{PBS} /$ casein $(2 \mu \mathrm{l} / 11 \mathrm{ml})$. Plates were washed again with $\mathrm{PBS}$, p-nitrophenyl phosphate substrate was added and incubated in dark for 15 minutes. Optic density values were measured in spectrophotometer at $405 \mathrm{~nm}$. Cut off value of assay was considered to mean absorbance of wells containing negative control samples +3 standard deviation of it, higher absorbance values of it were counted as positive.

\subsection{Sodium Dodecyl Sulfate-Polyacrylamide Gel Electrophoresis (SDS-PAGE) and Western Blotting (WB)}

Electrophoresis was performed using Mini Protein Slab Cell (Bio-Rad, USA) on a $12 \%$ SDS-polyacrylamide separating gel and $4 \%$ stacking gel under reducing conditions as previously described [2]. $7 \mu$ Standard Molecular Weight (SMW) (Bio-Rad, USA) was also loaded on both sides to determine the molecular weight of proteins. Electrophoresis was performed at $60 \mathrm{~V}$ for two hours at room temperature. Then, proteins electrophoretically transferred onto nitrocellulose membranes $(0.45 \mathrm{~mm}$, Bio-Rad $)$ at $300 \mathrm{~mA}$ for one hour at $4^{\circ} \mathrm{C}$. For blocking procedure, membrane was shaken within 5\% skimmed milk in TBS-t (0.2\% Tween20-TBS) for 30 minutes at room temperature. Following blocking, membrane was cut into approximately $2.5 \mathrm{~mm}$ wide strips. And every strip was incubated with 1:100 diluted sera in $0.5 \%$ skimmed milk-TBS-t for an hour on shaker at room tempera- 
ture. After three washes with TBS-t, strips were incubated for one hour with 1:5000 diluted Anti-Human IgG ( $\gamma$-chain specific) ALP (Sigma, GERMANY) in $0.5 \%$ skimmed milk-TBS-t. Strips were washed again 3 times then, bands were detected using 5-bromo-4-chloro-3-indolyl phosphate/nitroblue tetrazolium (BCIP/NBT, Sigma) in $100 \mathrm{mM}$ Tris- $\mathrm{HCl}$ with $100 \mathrm{mM} \mathrm{NaCl}$ and $5 \mathrm{mM} \mathrm{MgCl}_{2}$ for $15 \mathrm{~min}$ at room temperature.

\subsection{Statistical Analysis}

Statistical analysis was performed using Microsoft Excel (Excel 2010; Microsoft Corp., Redmond, WA) and mean, standard deviation, sensitivity, specificity values of tests were calculated.

\subsection{Ethical Approval and/or Informed Consent}

Patients were informed about diseases and procedure of this study. Informed written consent was obtained from each participant. Following to be given informed consent, they participated in the study. The study was approved by the local Clinical Research Ethical Committee.

\section{Results}

Of the 40 analyzed patients, ten (25\%) were men and 30 (75\%) were female. The average age was 46.97 years (s.d.; 18.95) and the youngest patient was 17 and the oldest 80 years old. The majority of the patients had single cystic lesion situated in one lobe of the liver (usually in the right lobe) (55\%), 32.5\% of patients had two cystic lesions and $12.5 \%$ of patients had multiple cyst formations with various numbers. In all cases, ultrasound (US) examinations were positive and the size of cysts was between $2.1-12.7 \mathrm{~cm}$. But only twenty-three patients of the total 40 patients were classified according to the WHO classification system based on US findings as follows: CL (1 patient), CE1 (4 patients), CE2 (7), CE3 (7), CE4 (2), CE4-CE5 (1), CE1-CE2 (1).

Serum samples of 40 patients were reactive in two serologic tests; IHA and ELISA. IHA titers of these serum samples were greater than 1/320. IHA titers of 2 patients, 6 patients, 9 patients and 23 patients were 1/320,1/640,1/1280 and 1/2500, respectively (Figure 1(a)). The ELISA titers of 40 patients were range from $1 / 640$ to $1 / 5000$. The data of Figure 1 (b) showed that 8 patients were $1 / 640,4$ patients were $1 / 1280,9$ patients were $1 / 2500,19$ patients were $1 / 2500$.

Western blot analysis of sera from 40 patients showed numerous bands against crude HCF. The molecular weight of bands were $8 \mathrm{kDa}, 12 \mathrm{kDa}, 22-24$ $\mathrm{kDa}, 26 \mathrm{kDa}, 34 \mathrm{kDa}, 36-38 \mathrm{kDa}, 45-50-55 \mathrm{kDa}, 60-75 \mathrm{kDa}$ (Table 1 and Figure 2). Both of two immunogenic polypeptides $(8 \mathrm{kDa}$ and $12 \mathrm{kDa})$ detected in $32(80 \%)$ patients. Furthermore, sera from 16 patients with other parasitic diseases and healthy individuals did not show any reactivity with these two polypeptides. Hence, they showed \%100 specificity. 
When the 16 serum samples from patients with other parasitic diseases were tested by Western blot, weak bands with molecular weights $24 \mathrm{kDa}, 34 \mathrm{kDa}, 38$ $\mathrm{kDa}, 50$ - $55 \mathrm{kDa}$ were recognized which are given in Table 2.
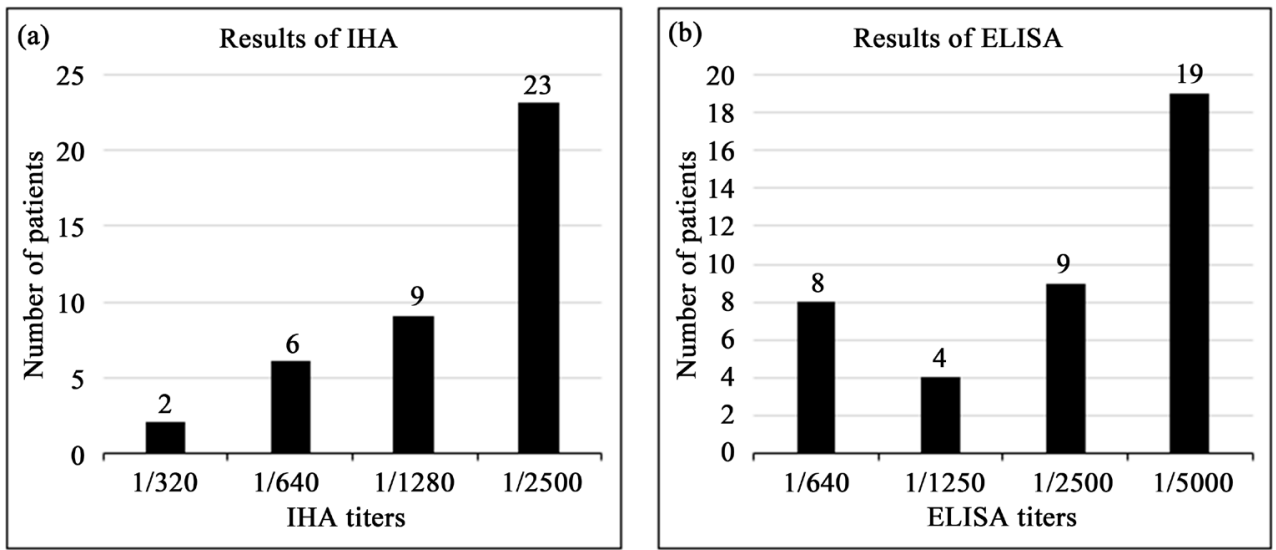

Figure 1. Serological findings with IHA test (a) and ELISA test (b) in patients with a cystic lesion of the liver.

Table 1. The number of bands and percentage were showed strong reactivity against sera of HCE patients.

\begin{tabular}{ccccccccc}
\hline $\begin{array}{c}\text { Molecular } \\
\text { Weight }\end{array}$ & $\begin{array}{c}\mathbf{8} \\
\mathrm{kDa}\end{array}$ & $\begin{array}{c}\mathbf{1 2} \\
\mathrm{kDa}\end{array}$ & $\begin{array}{c}\mathbf{2 2}-\mathbf{2 4} \\
\mathrm{kDa}\end{array}$ & $\begin{array}{c}\mathbf{2 6} \\
\mathrm{kDa}\end{array}$ & $\begin{array}{c}34 \\
\mathrm{kDa}\end{array}$ & $\begin{array}{c}36-38 \\
\mathrm{kDa}\end{array}$ & $\begin{array}{c}45-50-55 \\
\mathrm{kDa}\end{array}$ & $\begin{array}{c}60-75 \\
\mathrm{kDa}\end{array}$ \\
\hline $\begin{array}{c}\text { Number of } \\
\text { patients }\end{array}$ & 32 & 32 & 27 & 38 & 36 & 35 & 34 & 39 \\
\begin{tabular}{c} 
Percentage \\
\hline
\end{tabular} & $80 \%$ & $80 \%$ & $68 \%$ & $95 \%$ & $90 \%$ & $88 \%$ & $85 \%$ & $98 \%$ \\
\hline
\end{tabular}

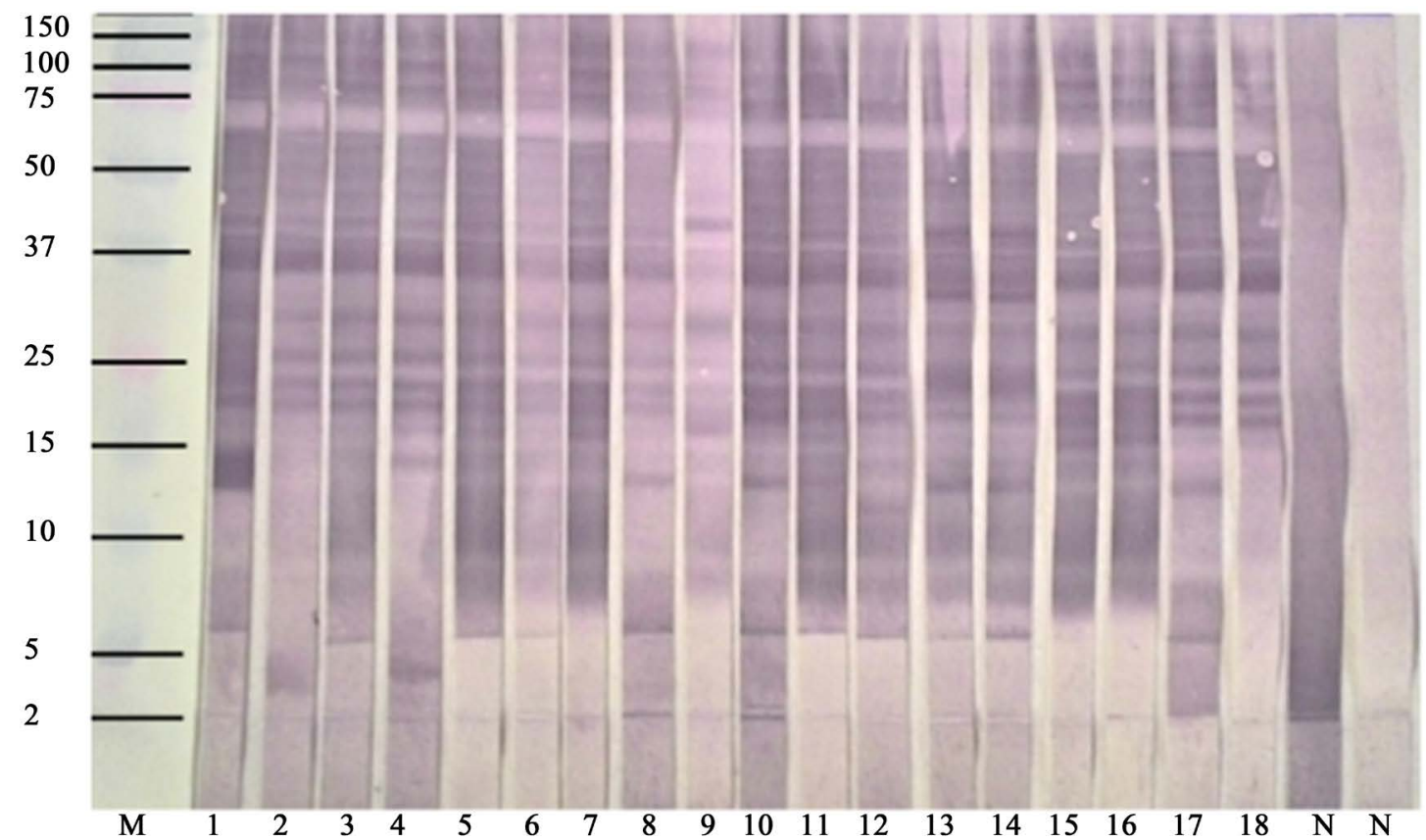

Figure 2. Western blot analysis of selected sera of HCE patients (M: Molecular weight standard; N: Negative; 1-18: HCE patients). 
Table 2. The molecular weights of cross-reaction with other parasitic diseases.

\begin{tabular}{cc}
\hline Disease & Molecular Weight (kDa) \\
\hline Fascioliasis (n: 5) & $34-38 \mathrm{kDa}$ (weak) \\
Toxocariasis (n: 4) & $24 \mathrm{kDa}, 38 \mathrm{kDa}, 55 \mathrm{kDa}$ (weak) \\
Trichinellosis (n: 3) & $34 \mathrm{kDa}, 50-55 \mathrm{kDa}$ (weak) \\
Leishmaniasis (n: 3) & $34 \mathrm{kDa}$ (weak) \\
Giardiasis (n: 1) & $24 \mathrm{kDa}, 38 \mathrm{kDa}, 50-55 \mathrm{kDa}$ (weak) \\
\hline
\end{tabular}

\section{Discussion}

The clinical management of CE in Turkey is based on a patient's anamnesis, clinical symptoms, morphological changes identified by imaging techniques and confirmed serologically. Ultrasound is the imaging technique of choice for the diagnosis of abdominal CE. Liver cysts appear to grow at a lower rate than lung cysts [19]. Clinical symptoms usually occur when the cyst compresses or ruptures into neighbouring structures. The serological diagnosis plays a key role not only in early detection of the infection as well as follow-up of the patients and usually, but liver cysts also produce a higher antibody response than the other locations of the cysts. The same results were detected in our HCE patients.

Seropositivity in females in this study was higher than in males. This finding could be explained by women are exposed to contact with sources of infection such as dogs, soil and raw vegetable. A similar observation was made by some authors in Turkey [20] [21] [22], in Iran [23], in western Azerbaijan [24] and in China [25].

Different antigens have been used for serodiagnosis of CE. It is known that HCF is a useful antigen source for serodiagnosis of human CE [26]. Lorenzo et al. [27] attributed the best diagnostic performance obtained with HCF antigen instead of recombinant AgB1 and B2 with sera from CE patients. Similarly, our results showed that crude HCF antigen using IgG ELISA and IHA provided better diagnostic performance. In this study, we also evaluated the diagnostic performance of crude native E. granulosus antigen that is easy to produce, cost-efficient tools for the serological diagnosis of $\mathrm{CE}$ and to assess its value in defined liver CE patients.

Enzyme-Linked Immunosorbent Assay (ELISA) and the commercial Indirect Hemagglutination Assay (IHA) techniques are frequently used in serodiagnosis of $\mathrm{CE}$ due to their ease of application and low cost. The most commonly used tests for the diagnosis of $\mathrm{CE}$ are based on hydatid fluid antigens of E. granulosus. These tests have relatively high sensitivities for hepatic ( $85 \%$ - 95\%) and multiple organ cysts (90\% - 100\%), but lower sensitivities for lung cysts (50\% - 60\%) [28] [29] [30]. ELISA test using crude HCF has a high sensitivity (over 95\%) but its specificity is often unsatisfactory. If purified antigens (e.g., antigen B) or other techniques (immunoblot analysis, detection of immunoglobulin G4 (IgG4) antibodies, immunoelectropheresis, etc.) are used, specificity is improved but av- 
erage sensitivity is much lower. Approximately $10 \%$ to $20 \%$ of patients with hepatic cysts and about $40 \%$ with pulmonary cysts do not produce detectable specific serum antibodies (IgG) and therefore give false-negative results [11] [31].

Sensitivity of serum antibody detection using IHA, ELISA, or latex agglutination, with HCF antigens, ranges between $85 \%$ and $98 \%$ for liver cysts, $50 \%-60 \%$ for lung cysts and $90 \%-100 \%$ for multiple organ cysts [16] [29] [30] [31]. Specificity of all tests is limited by cross-reactions due to other cestode infections ( $E$. multilocularis and Taenia solium), some other helminth diseases. Immunoblotting may be used as a first-line test and is best for differential diagnosis [32]. In our study, as expected, crude HCF antigen showed relatively low specificity (92.6\%) in both IHA and ELISA tests. Both methods showed 100\% sensitivity, however the sensitivity of WB was $80 \%$.

In our study, Western blot results identified 8 major antigenic structures in the range $8-75 \mathrm{kDa}$ in sheep HCF. In other reports, using hydatid fluid from sheep and camel cysts of E. granulosus, identified different 11 proteins in the range of $8-110 \mathrm{kDa}$ [33]. In our study, especially 8 and $12 \mathrm{kDa}$ bands were detected in 32 of 40 patients and no cross-reactivity with sera of other parasitic diseases. Our results indicate that WB may be the best single test to apply for the differential diagnosis of hepatic CE. But WB is expensive, requires specifically trained personnel for its interpretation, and is often used only as a confirmatory test.

In WHO Informal Working Group [7] on echinococcosis proposed the use of USG as the imaging technique of choice in order to promote uniform standards of CE diagnosis and follow-up. They also pointed out that US images suspected of showing CE should be confirmed by alternative diagnostic methods, such as serological techniques [34]. Only twenty-three patients of the total 40 patients were classified according to the WHO classification system based on USG findings as follows: CL (1 patient), CE1 (4 patients), CE2 (7), CE3 (7), CE4 (2), CE4 CE5 (1), CE1-CE2 (1). In 23 sera, we detected bands, however none of them was showed a specific band for CE1, CE2, CE3, CE4 and CE5 types.

In conclusion, our study showed that based on the tests evaluated here, an efficient approach to the serological diagnosis of cystic echninococcosis is primary testing with the crude E. granulosus. We also showed that it is easy-to-prepare and inexpensive metacestode-derived native antigens of $E$. granulosus are valuable tools for the diagnosis of CE in clinical settings. From a diagnostic perspective, $8 \mathrm{kDa}$ and $12 \mathrm{kDa}$ bands are sufficient to determine the specific diagnosis of HCE patients, too.

\section{Conflicts of Interest}

The authors declare no conflicts of interest regarding the publication of this paper.

\section{References}

[1] Moro, P. and Schantz, P.M. (2009) Echinococcosis: A Review. International Journal 
of Infectious Diseases, 13, 125-133. https://doi.org/10.1016/j.ijid.2008.03.037

[2] Yolasigmaz, A., Reiterová, K., Turk, M.,Reyhan, E., Bozdag, A.D., Karababa, A.O. and Altintas, N. (2006) Comparison of Serological and Clinical Findings in Turkish Patients with Cystic Echinococcosis. Helminthologia, 43, 220-225. https://doi.org/10.2478/s11687-006-0041-x

[3] Pakala, T., Molina, M. and Wu, G.Y. (2016) Hepatic Echinococcal Cysts: A Review. Journal of Clinical and Translational Hepatology, 4, 39-46. https://doi.org/10.14218/JCTH.2015.00036

[4] Altintas, N. (2003) Past to Present: Echinococcosis in Turkey. Acta Tropica, 85, 105-112. https://doi.org/10.1016/S0001-706X(02)00213-9

[5] Altintas, N., Topluoglu, S., Yıldırım, A., Uslu, H., Ekşi, F., Ok, Ü.Z., Arslan, M.Ö., Kayaalp, C., Secer, M., Kılıç, S., Karaman, Ü., Beyhan, Y.E., Öncel, T., Okumuş, B., Erol, U., Sertkaya, B., Gülyaz, V., Keskinkılıç, B., Kara, F., Doğanay, M. and Alp Meşe, E. (2020) Current Situation Report of Cystic Echinococcosiis in Turkey. Tur kish Bulletin of Hygiene and Experimental Biology, 77, 1-51.

[6] Mirabilea, E., Solomona, N., Fieldsa P.J. and Macpherson C.N.L. (2019) Progress towards International Adoption of the World Health Organization Ultrasound Classification of Cystic Echinococcosis. Acta Tropica, 189, 6-9.

https://doi.org/10.1016/j.actatropica.2018.09.024

[7] World Health Organization Informal Working Group (2003) International Classification of Ultrasound Images in Cystic Echinococcosis for Application in Clinical and Field Epidemiological Settings. Acta Tropica, 85, 253-261.

https://doi.org/10.1016/S0001-706X(02)00223-1

[8] Hosch, W., Junghanss, T., Stojkovic, M., Brunetti, E., Heye, T., Kauffmann, G.W., et al. (2008) Metabolic Viability Assessment of Cystic Echinococcosis Using High-Field ${ }^{1} \mathrm{H}$ MRS of Cyst Contents. NMR in Biomedicine, 21, 734-754. https://doi.org/10.1002/nbm.1252

[9] Junghanss, T., da Silva A.M., Horton, J., Chiodini, P.L. and Brunetti, E. (2008) Clinical Management of Cystic Echinococcosis: State of the Art, Problems, and Perspectives. American Journal of Tropical Medicine and Hygiene, 79, 301-311. https://doi.org/10.4269/ajtmh.2008.79.301

[10] Brunetti, E., Kern, P. and Vuitton, D.A. (2010) Expert Consensus for the Diagnosis and Treatment of Cystic and Alveolar Echinococcosis in Humans. Acta Tropica, 114, 1-16. https://doi.org/10.1016/j.actatropica.2009.11.001

[11] Pawłowski, Z.S., Eckert, J., Vuitton, D.A., Ammann, R.W., Kern, P., Craig, P.S., et al. (2001) Echinococcosis in Humans: Clinical Aspects, Diagnosis and Treatment. In: Eckert, J., Gemmell, M.A., Meslin, F.-X. and Pawłowski, Z.S., Eds., WHO/OIE Manual on Echinococcosis in Humans and Animals. A Public Health Problem of Global Concern, World Health Organization, Paris, 20-72.

[12] Manzano-Román, R., Sánchez-Ovejero, C., Hernández-González, A., Casulli, A. and Siles-Lucas, M. (2015) Serological Diagnosis and Follow-Up of Human Cystic Echinococcosis: A New Hope for the Future? BioMed Research Internationa, 2015, Article ID: 428205. https://doi.org/10.1155/2015/428205

[13] Mamuti, W., Sako, Y., Nakao, M., Xiao, N., Nakaya, K., Ishikawa, Y., Yamasaki, H., Lightowlers, M.W. and Ito, A. (2006) Recent Advances in Characterization of Echinococcus Antigen B. Parasitology International, 55, S57-S62. https://doi.org/10.1016/j.parint.2005.11.008

[14] Rahimi, H., Sadjjadi, S. and Sarkari, B. (2011) Performance of Antigen B Isolated from Different Hosts and Cyst Locations in Diagnosis of Cystic Echinococcosis. 
Iranian Journal of Parasitology, 6, 12-19.

[15] Coudert, J., Ambroise-Thomas, P., Kien Truong, T. and Pothier, M.A. (1967) 1st Results Concerning the Serologic Diagnosis of Hydatid Cyst by a New Technic of Immunofluorescence on Slides. Bulletin de la Societe Pathologie Exotique Filiales, 60, 555-563.

[16] Sako, Y., Nakao, M., Nakaya, K., Yamasaki, H. and Ito A. (2006) Recombinant Antigens for Serodiagnosis of Cysticercosis and Echinococcosis. Parasitology International, 55, S69-S73. https://doi.org/10.1016/j.parint.2005.11.011

[17] Mariconti, M., Bazzocchi, C., Tamarozzi, F., Meroni, V., Genco, F., Maserati, R. and Brunetti, E. (2014). Immunoblotting with Human Native Antigen Shows Stage-Related Sensitivity in the Serodiagnosis of Hepatic Cystic Echinococcosis. American Journal of Tropical Medicine and Hygiene, 90, 75-79. https://doi.org/10.4269/ajtmh.13-0341

[18] Bradford, M.M. (1976) A Rapid and Sensitive Method for the Quantitation of Microgram Quantities of Protein Utilizing the Principle of Protein-Dye Binding. Analytical Biochemistry, 72, 248-254. https://doi.org/10.1016/0003-2697(76)90527-3

[19] Larrieu, E.J. and Frider, B. (2001) Human Cystic Echinococcosis: Contributions to the Natural History of the Disease. Annals of Tropical Medicine Parasitology, 95, 679-687. https://doi.org/10.1080/00034983.2001.11813685

[20] Tevfik, M., Aldemir, O., Karadaş, K., Çelik, T. and Daldal, N. (2000) Malatya Bölgesinde uniloküler kistik ekinokkozis. Türkiye Parazitoloji Dergisi, 24, 33-36.

[21] İnceboz, T., Altıntaş, N., Kahya, M. and Haskaraca, F. (2001) Manisa bölgesinde unilokuler kistik ekinokkozis. Türkiye Parazitoloji Dergisi, 25, 45-48.

[22] Ertug, S., Sarı, C., Gurel, M., Boylu, S., Çanakkalelioglu, L. and Şahin, B. (2002). Aydın ve çevresinde 1996-2000 yılları arasında ceraahi olarak saptanan kist hidatik olgular1. Türkiye Parazitoloji Dergisi, 26, 254-256.

[23] Moosazadeh, M., Abedi, G., Mahdavi, S.A., Shojaee, J., Charkame, A. and Afshari, M. (2016) Epidemiological and Clinical Aspects of Patients with Hydatid Cyst in Iran. Journal of Parasitic Disease, 41, 356-360. https://doi.org/10.1007/s12639-016-0803-4

[24] Hajipirloo, H. M., Bozorgomid, A., Alinia, T., Tappeh, K. and Mahmodlou, R. (2013) Human Cystic Echinococcosis in West Azerbaijan, Northwest Iran: A Retrospective Hospital Based Survey from 2000 to 2009. Iranian Journal of Parasitology, 8, 323-326.

[25] Li, T., Qiu, J., Yang, W., Craig, P.S., Chen, X., Xiao, N., et al. (2005) Echinococcosis in Tibetan Populations, Western Sichuan Province, China. Emerging Infectious Diseases, 11, 1866-1873. https://doi.org/10.3201/eid1112.050079

[26] McManus, D.P., Gray, D.J., Zhang, W. and Yang, Y. (2012) Diagnosis, Treatment, and Management of Echinococcosis. BMJ, 344, e3866. https://doi.org/10.1136/bmj.e3866

[27] Lorenzo, C. and Last, J.A. (2005) Gonzàlez-Sapienza GG. The Immunogenicity of Echinococcus granulosus Antigen Five Is Determined by Its Post-Translational Modifications. Parasitology, 131, 669-677. https://doi.org/10.1017/S0031182005008309

[28] Siles-Lucas, M.M. and Gottstein, B.B. (2001) Molecular Tools for the Diagnosis of Cystic and Alveolar Echinococcosis. Tropical Medicine \& International Health, 6, 463-475. https://doi.org/10.1046/j.1365-3156.2001.00732.x

[29] Ito, A. and Craig, P.S. (2003) Immunodiagnostic and Molecular Approaches for the Detection of Taeniid Cestode Infections. Trends in Parasitology, 19, 377-381. 
https://doi.org/10.1016/S1471-4922(03)00200-9

[30] Siracusano, A. and Bruschi, F. (2006) Cystic Echinococcosis: Progress and Limits in Epidemiology and Immunodiagnosis. Parassitologia, 48, 65-66.

[31] Eckert, J. and Deplazes, P. (2004) Biological, Epidemiological, and Clinical Aspects of Echinococcosis, a Zoonosis of Increasing Concern. Clinical Microbiology Reviews, 17, 107-135. https://doi.org/10.1128/CMR.17.1.107-135.2004

[32] Akisu, C., Bayram, D.S., Yuncu, G., Aksoy, U., Ozkoc, S., Bicmen, C., et al. (2005) Evaluation of IHA, ELISA and Western Blot Tests in diagnoSis of Pulmonary Cystic Hidatidosis. Tuberküloz ve Toraks, 53, 156-160.

[33] Al-Olayan, E.M. and Helmy, H. (2012) Diagnostic Value of Different Antigenic Fractions of Hydatid Cyst Fluid from Camel and Sheep in Kingdom of Saudi Arabia. Journal of Saudi Chemical Society, 16, 203-207. https://doi.org/10.1016/j.jscs.2011.01.001

[34] Tawfeek, G.M., Elwakil, H.S., El-Hoseiny, L., Thabet, H.S., Sarhan, R.M., Awad, N.S. and Anwar, W.A. (2011) Comparative Analysis of the Diagnostic Performance of Crude Sheep Hydatid Cyst Fluid, Purified Antigen B and Its Subunit (12 Kda), Assessed by ELISA, in the Diagnosis of Human Cystic Echinococcosis. Parasitology Research, 108, 371-376. https://doi.org/10.1007/s00436-010-2074-9 